\title{
KEMAMPUAN REPRODUKSI TUNGAU PREDATOR FAMILI PHYTOSEIIDAE PADA BERBAGAI KEPADATAN TETRANYCHUS URTICAE DAN POLEN TANAMAN DI SEKITAR TANAMAN SINGKONG (MANIHOT ESCULENTA CRANTZ)
}

\author{
Bambang Heru Budianto $^{1}$ \& Achmad Munadjat ${ }^{2}$ \\ ${ }^{1)}$ Laboratorium Entomologi-Parasitologi, Fakultas Biologi, Universitas Jenderal Soedirman \\ E-mail: bhbudianto@gmail.com \\ ${ }^{2)}$ Laboratorium Hama dan Penyakit Tumbuhan, Fakultas Pertanian, Universitas Jenderal Soedirman
}

\begin{abstract}
The reproduction ability of the predatory mite of Phytoseiidae family in some densities Tetranychus urticae and pollen of plant that grew around cassava (Manihot esculenta Crantz). The predatory mite of Phytoseiidae family have extensive cruising range that is not only found in cassava, but also a variety of weeds in cassava plants, such as Ageratum conyzoides and Cyperus cyperus. Extensive cruising range is also well explain the survival rate of the Phytoseiidae family at the time of the density of T. urticae decreased. The research objective is to determine the development period, fecundity and survival rate of Phytoseiidae predatory mite populations at different relative densities T. urticae and pollen. The research method used is an experimental laboratory. The procedure include the provision of $A$. conyzoides and $C$. rotundus pollen, the multiplication of predatory mite families Phytoseiidae, the determination of the development period, fecundity and survival rate of predatory mite families Phytoseiidae. The results showed that the length of time the development of predatory mites Amblyseius sp. and Phytoseius sp. faster one day of feeding on egg T. urticae feeding compared to the two types of pollen. Predatory mites survival rate Phytoseius sp. higher than the predatory mites Amblyseius sp. eggs fed T. urticae and both types of pollen. Similarly, the fecundity Phytoseius sp. higher than the mites Amblyseius sp. either fed eggs T. urticae as well as to two types of pollen.
\end{abstract}

Key words: development period, fecundity, survival rate, Phytoseiidae family, Tetranychus urticae

\begin{abstract}
ABSTRAK
Kemampuan reproduksi tungau predator famili phytoseiidae pada berbagai kepadatan Tetranychus urticae dan polen tanaman di sekitar tanaman singkong (Manihot esculenta Crantz). Tungau Famili Phytoseiidae mempunyai daya jelajah yang luas sehingga tidak hanya ditemukan pada singkong saja namun juga berbagai tanaman gulma di sekitar singkong, seperti Ageratum conyzoides dan Cyperus cyperus. Daya jelajah yang luas ini juga sekaligus menjelaskan kemampuan lulus hidup tungau famili Phytoseiidae pada saat kepadatan tungau hama T. urticae menurun. Tujuan penelitian adalah menentukan lama waktu perkembangan, kelulushidupan dan fekunditas populasi tungau predator famili Phytoseiidae pada berbagai kepadatan T. urticae dan polen tanaman di sekitar tanaman singkong. Metode penelitian yang dipergunakan adalah eksperimental laboratorium. Cara kerja meliputi penyediaan polen A. conyzoides dan C. rotundus, perbanyakan tungau predator famili Phytoseiidae, penentuan lama waktu perkembangan, kelulushidupan dan fekunditas tungau predator famili Phytoseiidae. Hasil penelitian menunjukkan bahwa lama waktu perkembangan tungau predator Amblyseius sp. dan Phytoseius sp. lebih cepat satu hari pada pemberian pakan telur T. urticae dibandingkan pemberian pakan kedua jenis polen. Kelulushidupan tungau predator Phytoseius sp. lebih tinggi dibandingkan tungau predator Amblyseius sp. yang diberi pakan telur T. urticae dan kedua jenis polen. Demikian pula dengan fekunditas Phytoseius yang lebih tinggi dibandingkan tungau Amblyseius sp. baik diberi pakan telur T. urticae maupun kedua jenis polen.
\end{abstract}

Kata kunci: lama waktu perkembangan, fekunditas, kelulushidupan, tungau predator famili Phytoseiidae, Tetranychur urticae

\section{PENDAHULUAN}

Indonesia merupakan negara penghasil singkong ke-5 dengan produksi 18,9 juta ton per tahun dan hanya mampu memenuhi $15 \%$ saja dari total permintaan negara China (Rubijantoro, 2011). Sedangkan produsen singkong dunia terbesar masing-masing Nigeria, Somalia, Thailand dan Brazil. Rendahnya produksi singkong Indonesia 
dibanding empat negara tersebut selain rendahnya harga singkong, juga tidak lepas dari persoalan produksi dan efisiensi yang membekap perkebunan singkong di Indonesia (Lestarini, 2010).

Menurunnya produksi singkong, salah satunya disebabkan oleh hama. Lebih dari 200 spesies hama tanaman ketela pohon terutama dari filum Arthropoda, telah lama diketahui. Dari berbagai hama utama tersebut, tungau Tetranychus urticae merupakan tungau hama yang paling banyak menimbulkan kerugian dan dapat menurunkan produksi hingga $60 \%$ hasil panen (Bellotti, 2002). Pada serangan yang parah, bisa menyebabkan seluruh mahkota daun rontok sehingga tanaman menjadi gundul (Bakker, 1994).

Penurunan produktivitas singkong yang disebabkan oleh tungau hama $T$. urticae meningkat karena adanya pengaruh perubahan iklim berupa pemanasan global, sebagaimana yang berlangsung sepanjang tahun 2010 yang terjadi hampir merata di seluruh wilayah Indonesia. Budianto \& Praktinyo (2009) menambahkan bahwa populasi tungau laba-laba ( $T$. urticae) lebih tahan terhadap perubahan iklim termasuk pemanasan global dibandingkan tungau predatornya.

Crooker (1985) dan Zundel et al. (2009) mengemukakan bahwa kondisi lingkungan seperti kelembaban udara yang rendah dan suhu yang tinggi akan menyebabkan terjadinya peningkatan populasi tungau hama dan menurunkan biodiversitas tungau predator. Luedeling et al. (2011) mengemukakan bahwa perubahan iklim berupa pemanasan global telah meningkatkan banyaknya generasi berbagai macam jenis tungau hama termasuk Tetranychidae di Kalifornia yang mencapai 14 sampai 20 dari semula 9 sampai 14 generasi. Populasi T. urticae biasanya berkembang pesat pada musim kemarau yaitu saat tanaman singkong menghadapi masalah kekeringan. Pada saat ini, daya tahan tanaman mengalami penurunan disebabkan terjadinya kerusakan daun akibat tungau hama ini, yang akan meningkatkan transpirasi pada malam hari. Kerusakan juga terjadi pada bagian epidermis serta kutikula daun yang menyebabkan hilangnya air dan menumpuknya karbohidrat pada daun. Penumpukkan karbohidrat ini merupakan kebutuhan pokok bagi perkembangan populasi tungau hama sehingga kelimpahannya akan meningkat pesat.

Disisi lain, pengendalian alamiah berbagai tungau predator famili Phytoseiidae yaitu Phytoseius amba, Amblyseius aeralis dan Euseius concordis (Budianto, 2001) tidak mampu berlangsung dengan sempurna akibat pemanasan global dan perubahan musim. Mortalitas yang besar pada tungau-tungau predator famili
Phytoseiidae akibat pemanasan global dan perubahan musim telah menyebabkan menyebabkan menurunnya biodiversitas dan diversifikasi pengendalian hayati alamiah (Skirvin \& Fenlon, 2003).

Tungau famili Phytoseiidae mempunyai daya jelajah yang luas sehingga tidak hanya ditemukan pada tanaman singkong saja namun juga berbagai jenis gulma di sekitar tanaman singkong, seperti Ageratum conyzoides dan Cyperus rotundus. Daya jelajah yang luas ini juga sekaligus menjelaskan kemampuan lulus hidup tungau famili Phytoseiidae pada saat kepadatan tungau hama, T. urticae rendah (Budianto \& Pratiknyo, 2007). Kemampuan menjelajah dan menyisir daun yang penuh dengan bulu-bulu daun juga akan berpengaruh terhadap keefektivannya sebagai agen pengendali hayati (McMurtry \& Croft, 1997).

Vucic-Pestic et al. (2010) mengemukakan bahwa pengendalian hayati alamiah dapat terganggu dengan adanya pemanasan global berupa penurunan interaksi antara predator dengan mangsanya dan menurunnya laju predasi yang berakibat lanjut pada menurunnya laju reproduksi tungau predator. Menurunnya laju reproduksi tungau predator Iphiseius degenerans (Berlese) sangat bergantung pada kondisi temperatur (Tsoukanas et al., 2006) Hasil penelitian Tsoukanas et al. (2006) dan Logan et al. (2006) memberikan informasi bahwa jenisjenis tungau predator tertentu mampu beradaptasi terhadap perubahan musim dan kenaikkan temperatur akibat pemanasan global.

Selain temperatur, faktor kelangkaan pakan juga mempengaruhi kemampuan reproduksi tungau predator. Budianto (2001) mengemukakan bahwa kelangkaan pakan dapat mengurangi lama waktu perkembangan, kelulushidupan dan fekunditas tungau predator. Komponen-komponen reproduksi tersebut menjadi faktor utama dinamika populasi tungau predator, yang pada akhirnya mempengaruhi efektivitas pengendalian hayati alamiah terhadap tungau hama, T. urticae. Meskipun demikian, belum diketahui kemampuan reproduksi tungau predator famili Phytoseiidae yang mempredasi tungau hama $T$. urticae sebagai pakan utama dan pada kondisi kelangkaan pakan utama.

Berdasarkan asumsi-asumsi tersebut maka tujuan penelitian ini adalah untuk menentukan lama waktu perkembangan populasi tungau predator famili Phytoseiidae pada berbagai kepadatan relatif T. urticae dan polen tanaman di sekitar tanaman singkong. Menentukan kelulushidupan populasi tungau predator famili Phytoseiidae pada berbagai kepadatan relatif $T$. urticae dan polen tanaman di sekitar tanaman singkong. Menentukan fekunditas populasi tungau predator famili 
Phytoseiidae pada berbagai kepadatan relatif $T$. urticae dan polen tanaman di sekitar tanaman singkong.

\section{METODE PENELITIAN}

Tempat dan Waktu. Tempat pengambilan sampel berupa daun singkong adalah di perkebunan singkong Desa Banteran, Kecamatan Sumbang, kabupaten Banyumas. Pengamatan sampel yang didapat serta percobaan kemampuan reproduksi tungau predator famili Phytoseiidae dilakukan di Laboratorium Entomologi-Parasitologi, Fakultas Biologi, Universitas Jenderal Soedirman, Purwokerto. Penelitian dilaksanakan dari Juni sampai November 2011.

Penyediaan Polen Ageratum conyzoides dan Cyperus rotundus. Penyediaan polen A. conyzoides dan $C$. rotundus meliputi pengambilan dan penyimpanan polen menggunakan metode Klashorst (1996). Polen diambil dari anthera bunga dan kemudian disimpan dalam cawan petri. Cawan petri berisi anthera ini disimpan dalam inkubator pada suhu $60^{\circ} \mathrm{C}$ selama sekitar $12 \mathrm{jam}$, untuk tujuan sterilisasi. Setelah itu, polen dipisahkan dari anthera menggunakan sikat halus dan dimasukkan dalam botol kecil, lalu disimpan dalam lemari es. Polen dalam botol kecil ini tetap segar sampai satu tahun.

\section{Perbanyakan Tungau Predator Famili} Phytoseiidae. Perbanyakan tungau predator berdasarkan metode Overmeer et al. (1982) dalam Klashorst (1996). Sejumlah daun singkong yang memperlihatkan gejala serangan tungau hama T. urticae dipetik dan dimasukkan ke dalam kantong plastik. Di laboratorium, seluruh daun tersebut diperiksa di bawah mikroskop binokuler. Tungau famili Phytoseiidae yang diperoleh, dipindah ke tempat pemeliharaan, yang terdiri atas nampan plastik berisi air dengan busa di dalamnya. Di atas busa yang basah, diletakkan "black tile" yang bagian tepinya ditaruh kertas tissue yang tidak berparfum. Bagian ujung kertas terendam dalam air, sedangkan di atas kertas dibuat tanggul yang mengelilingi "black tile" menggunakan lem "tangle foot". Tanggul lem ini untuk mencegah agar tungau predator tidak melarikan diri dari arena uji. Jenis pakan alternatif yang diberikan adalah polen $A$. conyzoides dan $C$. rotundus. Dengan demikian, tempat pemeliharaan tungau predator tersusun atas 2 tempat pemeliharaan yang berbeda oleh karena pemberian pakan tidak hanya berupa telur T. urticae (Budianto \& Pratiknyo, 2009) tetapi juga jenis pakan alternatif diberikan tidak sama.
Penentuan Lama Waktu Perkembangan Tungau Predator Famili Phytoseiidae. Dalam percobaan ini, diambil 15 buah telur tungau predator famili Phytoseiidae dari tempat perbanyakan, yang oviposisinya terjadi pada hari yang sama (satu cohort). Telur-telur ini hingga menjadi tahap dewasa diinkubasikan pada temperatur $30^{\circ} \mathrm{C}$. Dicatat saat menetas, lama waktu hidup tahap larva, saat pergantian kulit menjadi nimfa, lama waktu hidup tahap nimfa, saat pergantian kulit menjadi tahap dewasa, dan lama waktu tahap dewasa. Pemberian polen $A$. conyzoides dan $C$. rotundus diberikan ad libitum pada tahap nimfa dan dewasa, oleh karena tahap larva tungau famili Phytoseiidae merupakan tahap tidak makan, sedangkan pemberian pakan utama berupa telur T. urticae sebanyak 4 butir setiap hari untuk satu ekor tungau predator famili Phytoseiidae.

\section{Penentuan Kelulushidupan Tungau Predator} Famili Phytoseiidae. Dalam percobaan ini, 15 buah telur tungau predator predator famili Phytoseiidae diinkubasikan pada temperatur $30{ }^{\circ} \mathrm{C}$ sampai menjadi tahap dewasa dan dicatat banyaknya kematian tahap telur, banyaknya kematian tahap larva, banyaknya kematian tahap nimfa, dan banyaknya kematian tahap dewasa. Banyaknya individu tungau predator predator famili Phytoseiidae yang lulus hidup pada tahap dewasa menunjukkan kemampuannya dalam menghadapi kondisi berbagai temperatur inkubasi dan jenis pakan alternatif yang diberikan. Pemberian pakan untuk tahap nimfa dan dewasa tungau predator terdiri atas 4 butir telur $T$. urticae untuk setiap ekornya dan pakan alternatif berupa polen $A$. conyzoides dan $C$. rotundus yang diberikan ad libitum.

Penentuan Fekunditas Tungau Predator Famili Phytoseiidae. Dalam percobaan ini, 4 ekor tungau predator betina dan 1 ekor tungau predator jantan famili Phytoseiidae yang telah matang secara seksual, diinkubasikan pada temperatur $30^{\circ} \mathrm{C}$ untuk setiap unit percobaan. Setiap harinya, tungau predator diberi pakan utama telur T. urticae dan pakan alternatif kedua jenis pollen. Pencatatan banyaknya telur yang dioviposisikan oleh satu ekor tungau predator betina famili Phytoseiidae per harinya dilakukan hanya untuk satu kopulasi. Setiap kali telah terjadi kopulasi, maka tungau predator jantan dikeluarkan dari tempat inkubasi untuk menghindari multiple mating.

Seluruh data yang diperoleh baik lama waktu perkembangan, kelulushidupan maupun fekunditas dianalisis dengan menggunakan analisis deskriptif dengan menyajikan dalam bentuk histogram. 


\section{HASIL DAN PEMBAHASAN}

Jenis-jenis Tungau Predator Famili Phytoseiidae. Hasil identifikasi jenis-jenis tungau predator famili Phytoseiidae, diperoleh dua jenis yaitu Phytoseius sp. dan Amblyseius sp. Hasil penelitian ini berbeda dengan hasil penelitian Budianto (2001) yang mendapatkan 3 jenis tungau predator famili Phytoseiidae, yaitu Amblyseius sp., Phytoseius sp. dan Euseius sp. Diduga kuat, pemanasan global berkorelasi dengan perubahan biodiversitas tungau predator famili Phytoseiidae. Crooker (1985) dan Zundel et al. (2009) mengemukakan bahwa menurunnya biodiversitas tungau predator sangat berkaitan dengan kondisi lingkungan seperti kelembaban udara yang rendah dan suhu yang tinggi.

Kedua jenis tungau predator yang ditemukan yaitu Phytoseius sp. dan Amblyseius sp. bersifat kosmopolitan dan menyebar dalam area yang sangat luas sehingga dapat ditemukan pula pada berbagai tanaman perkebunan antara lain teh, mangga, jeruk dan apel. Hal ini sesuai dengan pendapat Budianto (2001) yang menyatakan bahwa Phytoseius sp. dan Amblyseius sp. merupakan tungau predator dengan jelajah yang sangat luas. Kemampuan menyebar yang tinggi ini menjelaskan kemampuan kedua jenis tungau predator mencari iklim mikro untuk bertahan hidup dan melestarikan keturunannya. Hasil penelitian menunjukkan seluruh tungau predator dijumpai pada 4 sampai 5 tangkai terbawah tanaman singkong yang mempunyai temperatur lebih stabil berkisar $24^{0}$ sampai $26^{\circ} \mathrm{C}$ di siang hari (pukul 12.00-13.00 WIB) dengan kelembaban udara mencapai 78\%. Telur Phytoseiidae sukses menetas pada kelembaban relatif sangat rendah di bawah $80 \%$ dan temperatur $\pm 25^{\circ} \mathrm{C}$.

Secara morfologi Phytoseius sp. mempunyai chelicerae dan palpus yang sama panjang, dorsal shield lunak, 4 buah setae yang sama panjang pada ujung idiosoma. Jumlah setae pada ventrianal shield 18 buah, 4 buah setae pada ujung anal dan 8 buah setae yang tersebar teratur di ventrianal shield, mempunyai ventrianal shield, sternal shield dan genital shield. Ukuran tubuh rata-rata $275 \mathrm{~m}$, warna tubuh bening jika belum mendapat mangsa sebagaimana dideskripsikan oleh Budianto (2001).

Berbeda dengan Phytoseius sp., Amblyseius sp. mempunyai ciri-ciri idiosoma lebih membulat, jumlah setae pada ventrianal shield 22 buah, 4 setae pada ujung anal yang tidak sama panjang, 8 buah setae di sekitar ventrianal shield yang letaknya tersebar teratur. Ukuran tubuh rata-rata mencapai $220 \mathrm{~m}$, dengan dorsal shield yang lunak, pada pedipalpus terdapat 5 segmen
(Budianto, 2001). Ciri tingkah laku yang dapat dilihat dari tungau predator Amblyseius sp. adalah cara berjalan yang kuat dan lincah yang nampak dari ditegakkannya idiosoma di atas keempat pasang kakinya yang dilangkahkan jauh-jauh serta sepasng chelicerae dan palpus yang senantiasa merunduk ke bawah mencari mangsa (Budianto, 2000).

\section{Lama Waktu Perkembangan Tungau Predator} Famili Phytoseiidae. Berdasarkan jenis tungau predator famili Phytoseiidae yang telah diperoleh maka penelitian lama waktu perkembangan, kelulushidupan dan fekunditas selanjutnya dilakukan pada ke dua jenis tungau predator. Hasil penelitian lama waktu perkembangan tungau predator Phytoseius sp. dan Amblyseius sp. menunjukkan lama waktu perkembangan tungau predator Phytoseius sp. yang lebih cepat 1,3 hari (11 hari dari telur menjadi stadium dewasa) dibandingkan tungau predator Amblyseius sp.(12,3 hari dari telur menjadi stadium dewasa). Meskipun demikian, apabila tungau predator Phytoseius sp. dan Amblyseius sp. diberi pakan polen $A$. conyzoides dan $C$. rotundus, lama waktu perkembangan keduanya masih lebih cepat 4 sampai 5 hari (Gambar 1 dan 2). Hasil penelitian lama waktu perkembangan tungau predator Phytoseius sp. dan Amblyseius sp. yang diberi pakan polen $A$. conyzoides masing-masing lebih cepat 1 hari sampai 1,1 hari ( 15 hari dan 16,3 hari dari stadium telur sampai dewasa) dibandingkan apabila diberi pakan polen $C$. rotundus $(16,1$ hari dan 17,3 hari dari stadium telur sampai dewasa).

Hasil penelitian mengenai lama waktu perkembangan tungau predator baik Phytoseius sp. maupun Amblyseius sp. yang diberi pakan T. urticae dan polen gulma yang tumbuh disekitar tanaman singkong menunjukkan bahwa jenis pakan T. urticae merupakan jenis pakan utama kedua jenis tungau predator tersebut. Sebagaimana dikemukakan oleh Bakker (1994) dan Budianto (2001) bahwa lama waktu perkembangan tungau predator famili Phytoseiidae lebih singkat 4 sampai 5 hari apabila mengkonsumsi pakan utama yaitu tungau hama $T$. urticae dibandingkan polen.

Hasil penelitian juga menjelaskan bahwa polen gulma $A$. conyzoides dan $C$. rotundus merupakan jenis pakan alternatif bagi tungau predator famili Phytoseiidae disaat pakan utama mengalami kelangkaan. Mondal et al. (1998) mengemukakan bahwa kandungan asam amino yang dimiliki oleh polen $A$. conyzoides berkisar 0,5 sampai $4 \%$ dari total berat kering dan tersusun oleh 14 jenis asam amino diantaranya asam amino-n-butyrat, asam aspartat, proline, arginine, cystine, asam glutamat, 


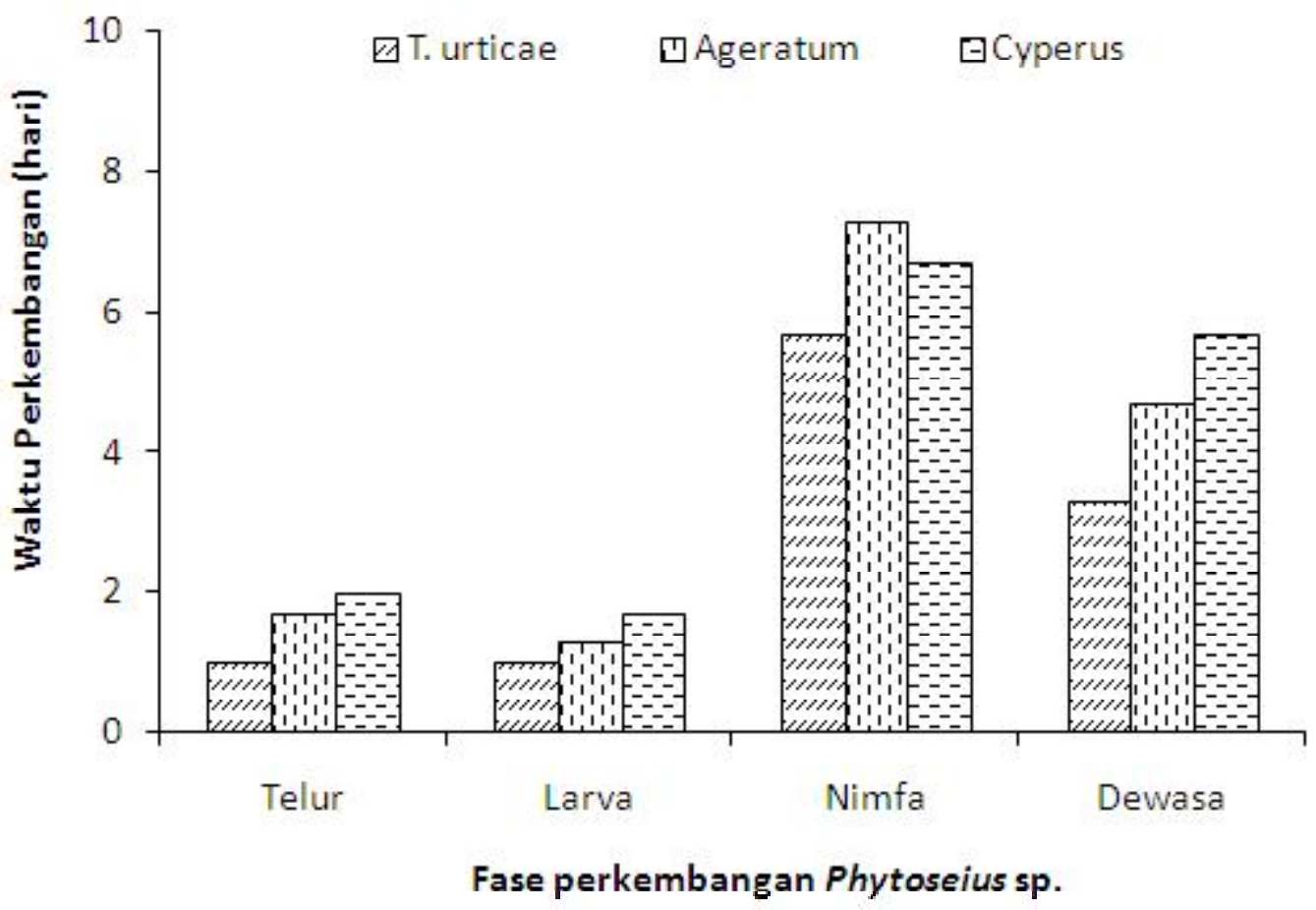

Gambar 1. Lama waktu perkembangan tungau predator Phytoseius sp. pada pemberian pakan telur T. urticae, polen Ageratum conyzoides dan Cyperus rotundus.

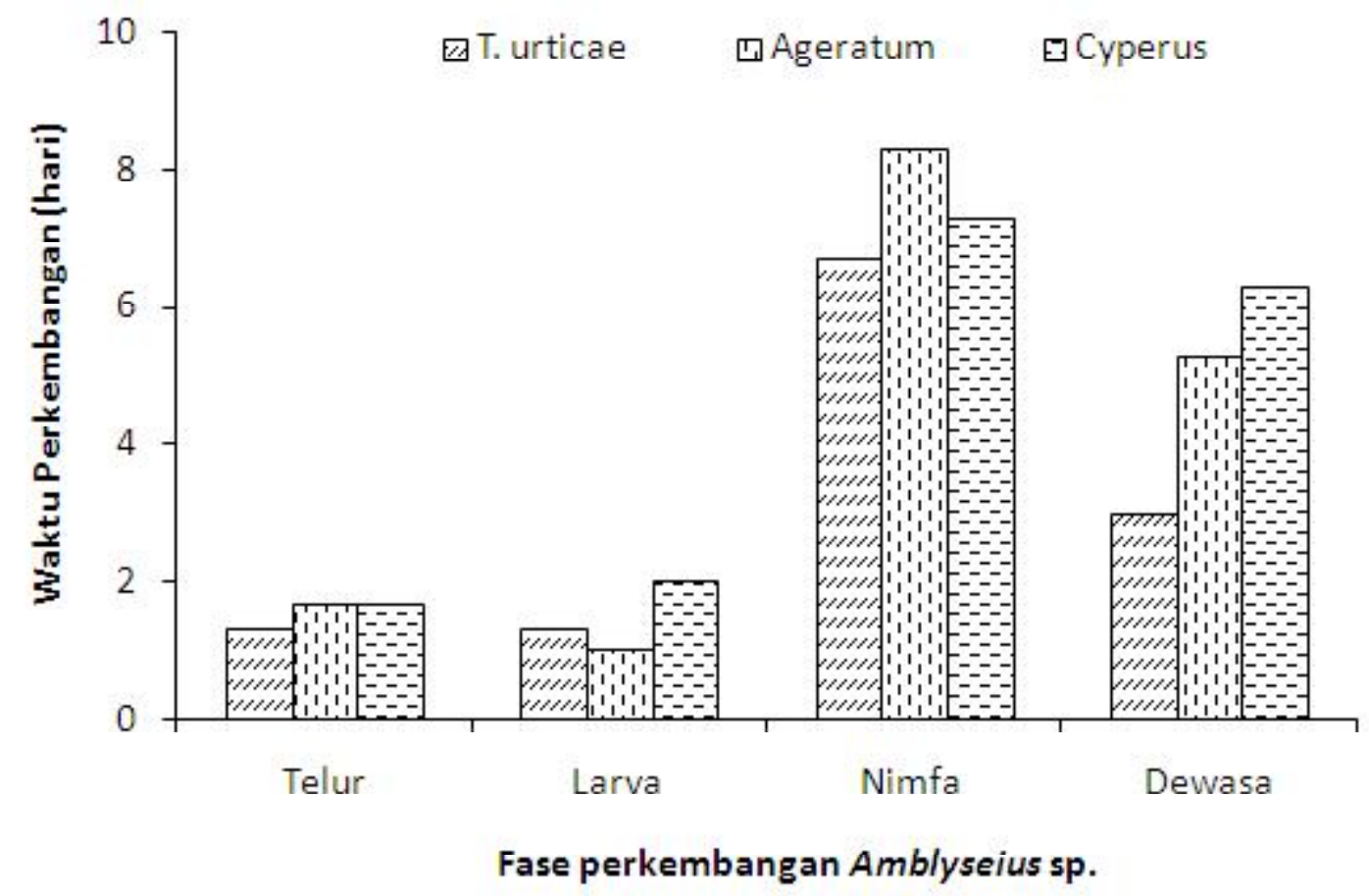

Gambar 2. Lama waktu perkembangan tungau predator Amblyseius sp. pada pemberian pakan telur T. urticae, polen Ageratum conyzoides dan Cyperus rotundus. 
glycine, isoleucine, leucine, methionine, ornithine, tryptophan dan tyrosine. Dibandingkan dengan polen $A$. conyzoides, polen $C$. rotundus mempunyai senyawa lebih kompleks terdiri atas konjugasi fruktosa-asam amino, N-(1-deoxy-alpha-D-fructos-1-yl)-L-tryptophan dan tautomernya, n-butyl-beta-D-fructopyranoside,ethylalpha-D-glucopyranoside, adenosine, asam (-)-(E)caffeoylmalic, vitexin, isovitexin, orientin, epiorientin, myricetin 3-O-beta-D-galactopyranoside, luteolin 7-Obeta-D-glucuronopyranoside-6"' -methyl ester, chlorogenic acid, luteolin 4'-O-beta-Dglucuronopyranoside, luteolin 7-O-beta-Dglucuronopyranoside, uridine, asam ellagic, berbagai senyawa antioksidan dan senyawa fenol yang memperlihatkan aktivitas alpha-amylase inhibitory (Sayed et al., 2005). Perbedaan komposisi kimiawi kedua jenis polen menjelaskan lama waktu perkembangan kedua jenis tungau predator dan preferensi tungau predator Phytoseius sp. dan Amblyseius yang lebih memilih polen A. conyzoides dibandingkan polen $C$. rotundus. Meskipun demikian, peneliti belum bisa menjelaskan jenis senyawa kimiawi polen apa saja yang menyebabkan terjadinya preferensi dan berdampak pada lama waktu perkembangan Phytoseius sp dan Amblyseius sp yang lebih singkat apabila mengkonsumsi polen $A$. conyzoides dibandingkan $C$. rotundus.

\section{Kelulushidupan Tungau Predator Famili} Phytoseiidae. Hasil pengamatan kelulushidupan tungau predator Phytoseius sp. dibandingkan Amblyseius sp. apabila mengkonsumsi telur $T$. urticae, baik pada stadium telur, larva, nimfa maupun dewasa lebih tinggi tungau predator Phytoseius sp. dibandingkan Amblyseius sp. (Gambar 3 dan 4). Lebih tingginya kelulushidupan tungau predator Phytoseius sp. dibandingkan Amblyseius sp. juga terlihat apabila kedua jenis tungau predator ini mengkonsumsi polen $A$. conyzoides dibandingkan apabila $C$. rotundus.

Hasil penelitian juga menjelaskan adanya fenomena yang menarik yaitu telur kedua jenis tungau predator yang sebelumnya diberi pakan telur T. urticae, polen $A$. conyzoides dan $C$. rotundus mempunyai kelulushidupan yang sama tinggi. Seluruh telur mampu menetas menjadi larva dan pada stadium larva, kedua jenis tungau predator ini masih mempunyai pola kelulushidupan yang sama dengan stadium telur. Penurunan kelulushidupan sangat besar pada kedua jenis tungau predator ini dijumpai pada saat memasuki stadium nimfa, baik mengkonsumsi telur T. urticae maupun kedua jenis polen. Meskipun demikian, setelah melewati

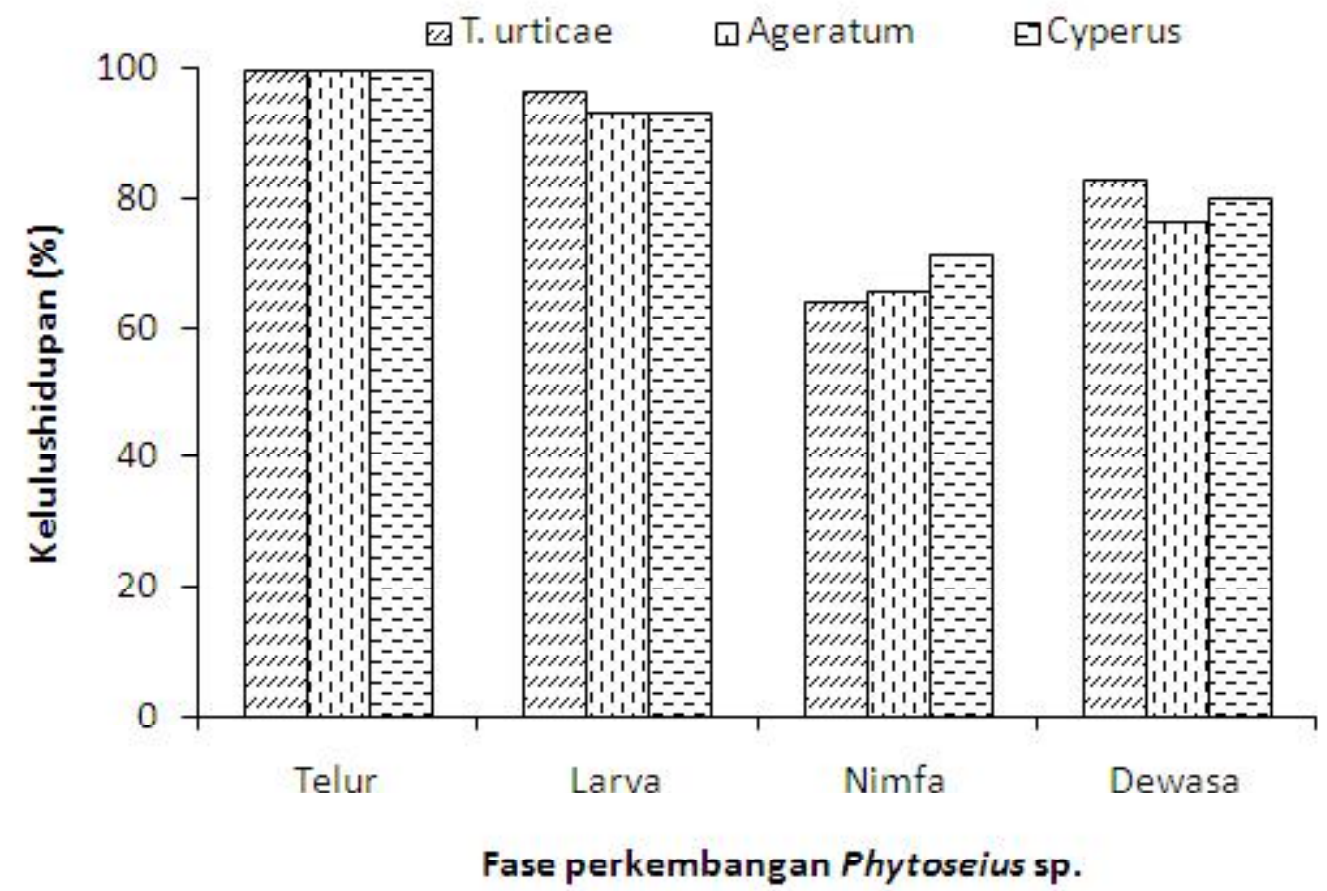

Gambar 3. Kelulushidupan tungau predator Phytoseius sp. pada pemberian pakan telur T. urticae, polen Ageratum conyzoides dan Cyperus rotundus. 


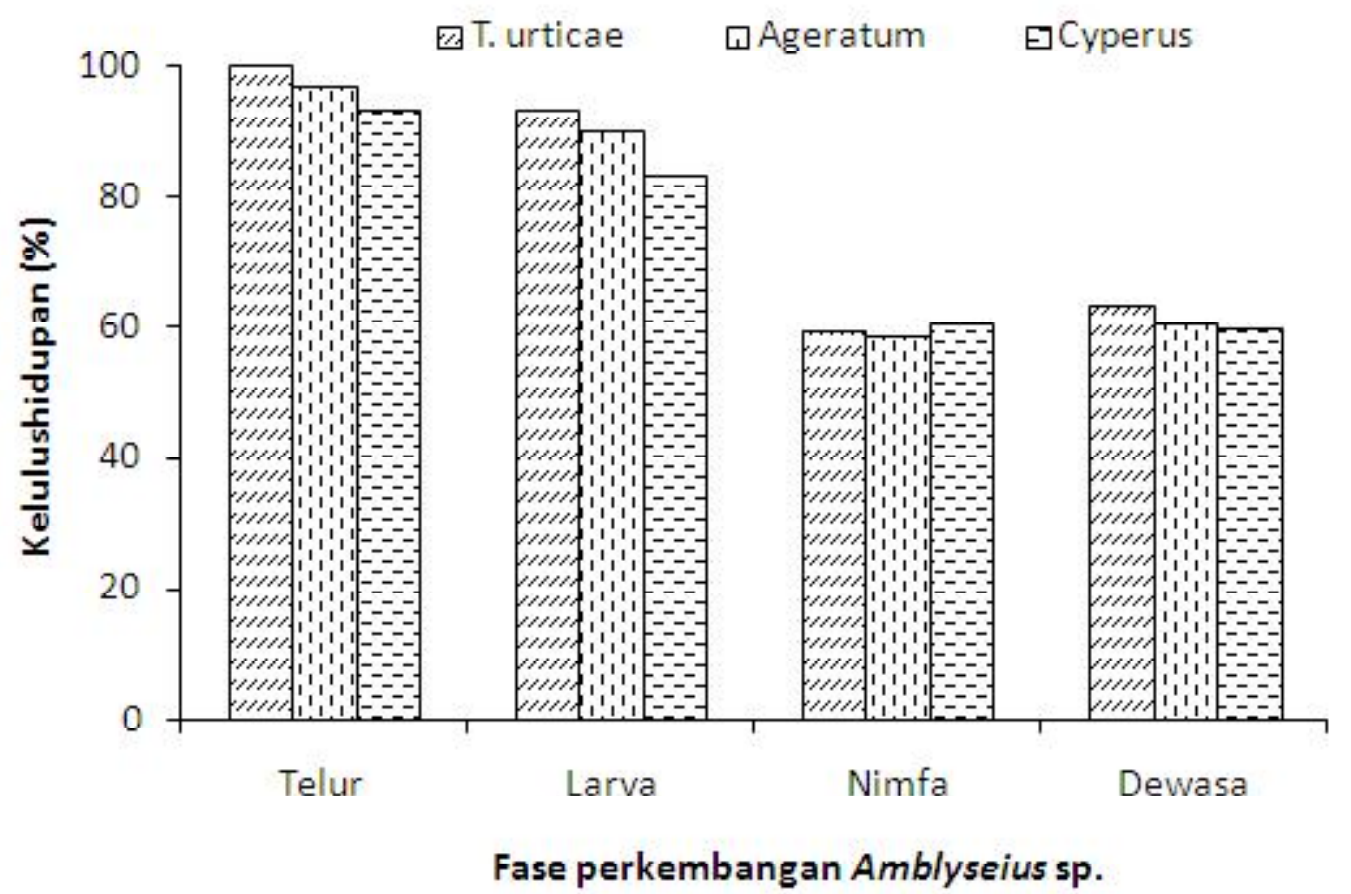

Gambar 4. Kelulushidupan tungau predator Amblyseius sp. pada pemberian pakan telur T. urticae, polen Ageratum conyzoides dan Cyperus rotundus.

stadium nimfa dan memasuki stadium dewasa, tungau predator Phytoseius sp. mempunyai kelulushidupan yang lebih tinggi dibandingkan Amblyseius sp. baik diberi pakan telur T. urticae, maupun ke dua jenis polen. Diduga mortalitas pada awal stadium nimfa dibandingkan stadium dewasa lebih dikarenakan oleh proses adaptasi terhadap polen dibandingkan pada pakan utama yaitu telur T. urticae. Proses adaptasi ini diduga berkaitan dengan kandungan senyawa kimiawi polen atau mungkin terhadap morfologi polen yang mempunyai struktur eksin berduri pada $C$. rotundus dibandingkan polen $A$. rotundus yang struktur eksinnya lebih halus (Meissner et al., 1979).

Fekunditas Tungau Predator Famili Phytoseiidae. Hasil pengamatan terhadap fekunditas kedua jenis tungau famili Phytoseiidae yang diberi pakan telur $T$. urticae, polen $A$. conyzoides dan $C$. rotundus menunjukkan bahwa tungau Phytoseius sp. mempunyai tingkat fekunditas yang lebih tinggi dibandingkan tungau Amblyseius sp. (Gambar 5).

Berdasarkan Gambar 5 diketahui bahwa pemberian pakan telur T. urticae merupakan sumber nutrien yang memberikan fekunditas rata-rata kedua jenis tungau predator famili Phytoseiidae paling tinggi dibandingkan pemberian dua jenis polen. Gambar 6 juga menginformasikan bahwa pemberian polen $C$. rotundus menyebabkan fekunditas rata-rata kedua jenis tungau predator lebih rendah dibandingkan pemberian pakan polen $A$. conyzoides apalagi apabila dibandingkan dengan pemberian telur T. urticae.

Tingginya kelulushidupan tungau predator famili Phytoseiidae pada pemberian pakan telur T. urticae dibandingkan pemberian pakan kedua jenis polen, menunjukkan bahwa kandungan nutrien telur dan tingkat konsumsinya berhubungan erat dengan banyaknya telur yang dihasilkan. McMurtry (1996) mengemukakan bahwa ada korelasi antara lama waktu perkembangan yang singkat dengan tingginya fekunditas. Terkait dengan lebih rendahnya fekunditas tungau predator famili Phytoseiidae apabila mengkonsumsi polen $C$. rotundus dibandingkan polen $A$. conyzoides, diduga berhubungan dengan kandungan senyawa alkaloid yang lebih tinggi pada polen $C$. rotundus dibandingkan polen A. conyzoides.

\section{SIMPULAN}

Hasil penelitian menunjukkan bahwa lama waktu perkembangan tungau predator Amblyseius sp. dan Phytoseius sp. lebih cepat satu hari pada pemberian pakan telur T. urticae dibandingkan pemberian pakan berupa polen. Kelulushidupan tungau predator Phytoseius sp. lebih tinggi dibandingkan tungau predator 


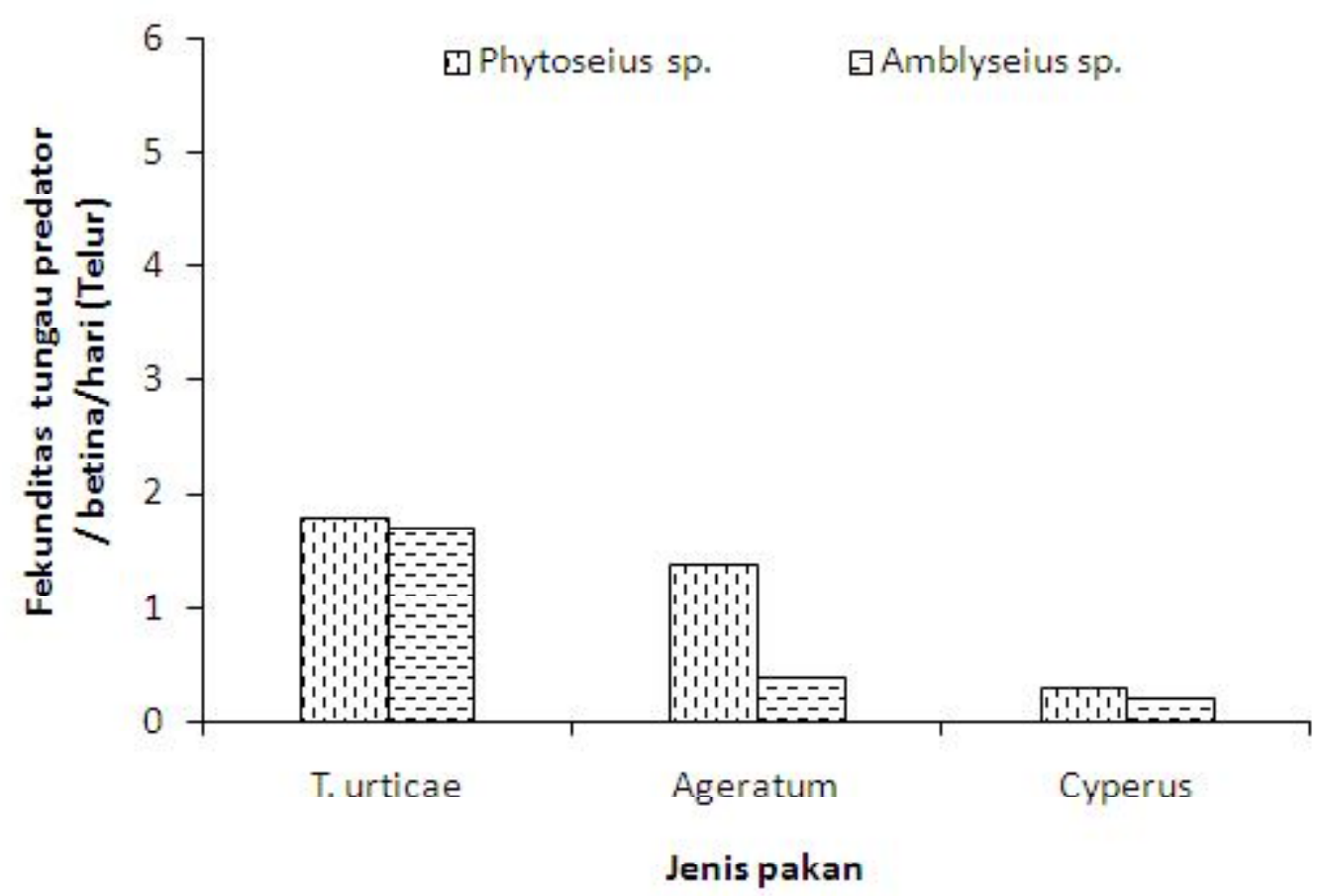

Gambar 6. Fekunditas rata-rata tungau predator Phytoseius sp. dan Amblyseius sp. yang diberi pakan telur T. urticae, Ageratum conyzoides dan Cyperus rotundus

Amblyseius sp. yang diberi pakan telur T. urticae dan kedua jenis polen. Fekunditas Phytoseius sp. lebih tinggi dibandingkan tungau Amblyseius sp. baik yang diberi pakan telur T. urticae maupun ke dua jenis polen.

\section{SANWACANA}

Peneliti mengucapkan terima kasih kepada ketua Lembaga Penelitian dan Pengabdian pada Masyarakat Universitas Jenderal Soedirman yang telah memberikan kesempatan dan dana untuk melakukan penelitian ini. Terima kasih peneliti sampaikan juga kepada tim reviewer dan monev yang telah menelisik usulan dan hasil penelitian ini sehingga kami mempunyai kesempatan mengekspresikan kemampuan meneliti kami.

\section{DAFTAR PUSTAKA}

Bakker FM. 1994. The selection of Phytoseiid natural enemies for the biological control of the cassava green mite. In: Selecting Phytoseiid Predator for Biological Control with Emphasis on the Significance of tritrophic Interaction. Disertation (Unpublished), University of Amsterdam.
Bellotti AC. 2002. Arthropod Pests. Pp. 209-234. In: Hillock RJ, Thresh JM \& Bellotti AC, Eds. Pest Cassava : Biology, Production and Utilization. $\mathrm{CAB}$ International.

Budianto BH. 2001. Seleksi tungau predator lokal yang potensial sebagai agen pengendali hayati tungau hama Tetranychus sp. pada tanaman singkong (Manihot esculenta Crantz). Laporan Penelitian, Fakultas Biologi, Unsoed, Purwokerto.

Budianto BH \& Pratiknyo H. 2007. Kemampuan Phytoseius crinitus memangsa setiap stadium Tetranychus urticae serta beberapa pakan alternative untuk perbanyakannya di laboratorium. Laporan Penelitian DUE-Like Unsoed, Purwokerto.

Budianto BH \& Pratiknyo H. 2009. Faktor kunci dan strategi pelepasan Phytoseius crinitus Swirski Et Schebter dalam pengendalian Tetranychus urticae pada tanaman singkong (Manihot esculenta). Laporan Penelitian RUSNAS, Unsoed, Purwokerto. 
Crooker A. 1985. Embrionic and Juveniel Development of Tetranychus urticae. In : Helle, W \& Sabelis MW, (eds.) Spider Mite: Their Biology Natural Enemies and Control. Elsevier, Netherlands.

Klashorst VDG. 1996. Integrated pest management of scarlet mite on tea using pesticide tolerant predaceous mites. Instituut voor Systematiek en Populatiebiologie. University of Amsterdam.

Lestarini AH. 2010. Pemerintah Disarankan Stabilkan Harga Singkong. Okezone.com. Diakses tanggal 27 April 2011.

Logan JD, W Wolesensky \& A Joern. 2006. Possible Impacts and Dynamics at Population, Species Interaction, and Community Levels. Climate Change and Global Food Security, CRC Press.

Luedeling E, Steinmann KP, Zhang MA, Brown PH, Grantz J \& Girvetz EH. 2011. Climate chage effects on walnut pests in California. Global Change Biology 17:228-238.

Meissner R, Nel PC \& Smith NSH. 1979. Influence of Red Nutgrass (Cyperus rotundus) on Growth and Development of Some Crop Plants. Pp.3952. Proc. $3^{\text {rd }}$ Natl. Weed Conf.S. Afr.

McMurtry JA \& Croft BA. 1997. Life-styles of Phytoseiid mites and their role in biological control, Ann. Review of Entomology 42: 291321.

Mondal AK, Parui S \& Mandal S. 1998. Analysis of the free amino acid content in pollen of nine Asteraceae species of known allergenic activity. Ann.Agric.Environ.Med. 5(1):17-20.
Rubijantoro Y. 2011. Permintaan singkong dari China Rp. 1,3 trilyun. Okezone.com. Diakses tanggal 27 April 2011.

Sayed HM, Mohamed MH, Farag SF, Mohamed GA, Omobuwajo OR \& Proksch P. 2005. Fructoseamino acid conjugate and other constituents from Cyperus rotundus L. http:// www.pubmedcentral.nih.gov

Skirvin DJ \& Fenlon JS. 2003. The effect of temperature on the functional response of Phytoseiulus persimilis (Acari: Phytoseiidae). Exp Appl Acarol. 31(1-2):37-49.

Tsoukanas VI, Papadopoulos GD, Fantinou AA \& Papadoulis GTh. 2006. Temperature-dependent development and life table of Iphiseius degenerans (Acari: Phytoseiidae). Environ. Entomol 35(2):212-218.

Vucic-Pestic O, Ehnes RB, Rall BC \& Brose U. 2010. Warming up the system: higher predator feeding rates but lower energetic efficiencies. Global Change Biology 17(3):1301-1310.

Zundel C, Nagel P, Hanna R, Korner F \& Schidegger U. 2009. Environment and host-plant genotype effects on the seasonal dynamics of a predatory mite on cassava in sub-humid tropical Africa. Agricultural and Forest Entomology. 